DOI: https://doi.org/10.15407/techned2018.05 $: \underline{011}$

\title{
THE PENETRATION OF NONUNIFORM ELECTROMAGNETIC FIELD OF CURRENT COUNTER IN CONDUCTING MEDIUM
}

Journal

Publisher

ISSN

Issue

Pages
Tekhnichna elektrodynamika

Institute of Electrodynamics National Academy of Science of Ukraine 1607-7970 (print), 2218-1903 (online)

No 5, 2018 (September/October)

$11-14$

\section{Authors}

Yu.M. Vasetsky, K.K. Dziuba, I.M. Kucheriava, I.L. Mazurenko

Institute of Electrodynamics National Academy of Sciences of Ukraine,

pr. Peremohy, 56, Kyiv, 03057, Ukraine,

e-mail: yuriy.vasetsky@gmail.com

\section{Abstract}

The reduction of nonuniform electromagnetic field created by current contour in conducting half-space is analyzed by analytical solution of three-dimensional field problem and numerical computation of the problem using program Comsol. As shown, the rate of the field reduction depends on skin depth. The greater the depth, the faster the rate of such field penetration. At strong skin-effect, the rate of field reduction is approximated to uniform field penetration for all points on the interface, and the disagreement is associated with the value of small parameter. $\mathrm{R}$ eferences 10, figures 4 . 
Key words: three-dimensional electromagnetic field, eddy current, field penetration, numerical and analytical methods.

Received: 02.03 .2018

Accepted: 14.03 .2018

Published: 16.08.2018

\section{References}

1. Stepanov G.V., Babutskiy A.I. Effect of high-density pulsed electric current on strength of metallic materials and stress-strain state of structural components. Kyiv: Naukova dumka, 2010. 276 p. (Rus)

2. Rudnev V., Loveless D., Cook R., Black M. Handbook of induction heating. Marcel Dekker Inc., 2003. $777 \mathrm{p}$.

3. Turenko A.N., Batyigin Yu.V., Gnatov A.V. Pulse magnetic fields for progressive technologies. Vol. 3: The theory and experiment of an attraction of thin-walled metals by pulse magnetic fields. Kharkov: HNADU, 2009. 240 p. (Rus)

4. Polivanov K.M. Theoretical bases of electrical engineers. Vol. 3. The theory of electromagnetic field. Moskva: Energiia, 1969. 352 p. (Rus)

5. Kravchenko A.N., Nizhnik L.P. Electrodynamic calculations in electrical engineering. Kyiv: Tekhnika, 1974. 184 p. (Rus)

6. Vasetsky Yu.M., Dziuba K.K. An analytical calculation method of quasi-stationary three-dimensional electromagnetic field created by the arbitrary current contour that located near conducting body. Tekhnichna Elektrodynamika. 2017. No 5. Pp. 7-17. (Rus)

7. Vasetsky Yu.M., Dziuba K.K. Three-dimensional quasi-stationary electromagnetic field generated by arbitrary current contour near conducting body. Tekhnichna Elektrodynamika. 2018. No 1. Pp. 3-12.

8. Tozoni O.V. Method of secondary sources in the electrical engineer. Moskva: Energiia, 1975. 296 p. (Rus)

9. Zommerfeld A. Elektrodynamics. Moskva: Izdatelstvo Inostrannoi literatury, 1958. 501 p. (Rus)

10. Vasetsky Yu.M., Kucheriava I.M., Mazurenko I.L., Dziuba K.K. Analytical and numerical 
determination of three-dimensional quasi-stationary electromagnetic field of alternating current contour near the conducting medium. Tekhnichna Elektrodynamika. 2018. No 4. Pp. 10-13. (Ukr)

$\underline{\text { PDF }}$ 